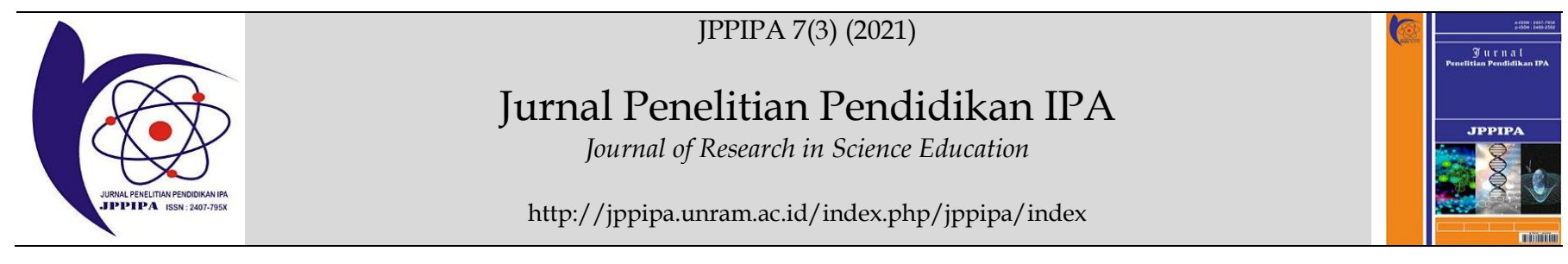

\title{
HOTS Assessment of Biology Cell: Validity, Practicality and Reliability
}

\author{
Yosi Laila Rahmi ${ }^{*}$, Nadiah Alhusna Miatidini ${ }^{1}$, Heffi Alberida ${ }^{1}$, Rahmawati Darusyamsyu ${ }^{1}$, \\ Ilmi Zajuli Ichsan², Diana Vivanti Sigit³, Titin, Isil Koc ${ }^{5}$, Maricar H. Sison ${ }^{6}$ \\ ${ }^{1}$ Biology Education Department, Faculty of Mathematics and Natural Science, Universitas Negeri Padang, Indonesia \\ ${ }^{2}$ Elementary Teacher Education Department, Faculty of Teacher Training and Education, Universitas MH Thamrin Jakarta, Indonesia \\ ${ }^{3}$ Biology Education Department, Faculty of Mathematics and Natural Science, Universitas Negeri Jakarta, Indonesia \\ ${ }^{4}$ Biology Education Department, Faculty of Teacher Training and Education, Universitas Tanjungpura, Indonesia \\ ${ }^{5}$ Science Education Department, Istanbul University, Turkey \\ ${ }^{6}$ College of Education, Nueva Ecija University of Science and Technology, Philippines
}

DOI: $\underline{10.29303 / \text { ippipa.v7i3.742 }}$

\section{Article Info}

Received : May 21 th, 2021

Revised : July 17th, 2021

Accepted: July 25th, 2021

\begin{abstract}
This study aims to produce an instrument for assessing high-order thinking skills about cell division material for students in class XII that are logically valid and empirically, practical and reliable. This study uses a 4D models development model consisting of the stages of defining, designing, developing, and disseminating. The dissemination stage was not carried out due to time and cost limitations. The subjects of this study were three validators consisting of two lecturers at the Department of Biology, Padang State University, and one teacher at Senior High School 2 Painan. Practicality was carried out by two biology teachers and 34 students of class XII of Senior High School 2 Painan. The data collection instruments were validation sheets and practicality tests. Data were analyzed using ANATES 4.09 application. The instrument for assessing high-order thinking skills about cell division material for class XII students who get an average logical validity value of $89.02 \%$ with valid criteria, the practical average value is $91.70 \%$ with very practical criteria. The empirical validity data analysis results obtained 37 questions out of 50 questions with a value of $74 \%$, reliability of 0.89 with very high criteria. It can be concluded that an instrument for assessing the ability to think at a higher level about cell purchasing material is logically valid and empirically valid, practical, and reliable.
\end{abstract}

Keywords: Assessment; Cell Division; HOTS.

Citation: Rahmi, Y.L., Miatidini, N.A., Alberida, H., Darussyamsyu, R., Ichsan, I.Z., Sigit, D., Titin, T., Koc, I., \& Sison, M. (2021). HOTS Assessment of Biology Cell: Validity, Practicality and Reliability. Jurnal Penelitian Pendidikan IPA, 7(3), 481-487. doi:https://doi.org/10.29303/jppipa.v7i3.742

\section{Introduction}

The curriculum is used as a learning tool that supports learning and teaching activities in education today. The 2013 curriculum has been implemented at all levels of education in Indonesia. The 2013 curriculum requires students to be more active and able to think critically, and it is hoped that teachers will act as facilitators in learning. "Learning is no longer centered on the teacher, but more centered on student activities so that learning is no longer one direction but more interactive (Mahoney \& Harris-Reeves, 2019; Sesen \& Tarhan, 2010). The cognitive domain consists of six levels: remembering, understanding, applying, analyzing, assessing, and creating. Cognitive levels to measure higher-order thinking skills include the ability to analyze (C4), evaluate (C5), and create (C6) according to (Anderson et al., 2001).

High-order thinking skills (HOTS) are very important to be applied and developed in learning. "If students have high-order thinking skills, then in learning they will be able to use problem-solving

\footnotetext{
*Email: yosibio@fmipa.unp.ac.id
} 
methods properly, and appropriately (Lince, 2016; Tajudin \& Chinnappan, 2016). Processing the information obtained is obtained by involving creative and critical thinking processes in the cognitive realm (analysis, evaluation, and creation) and dealing with certain situations or problems that require a solution.

In the establishment of a curriculum, planning is the first step. It entails assessing to determine the needs. Learners, teachers, community, and societal needs would all be considered as they relate to the curriculum. The learning outcomes are set after the needs have been identified. Teachers must develop strategies and methods to reach desired results. The support materials should also be written and include the means of evaluation.

Teachers are guided by following the principles of assessment. The teacher should use the assessment tools to reflect the knowledge and skills that are important to students; it should tell how students are progressing; the results should be consistent. Assessment should support every student's opportunity to learn important things; it should allow individuality or uniqueness to be demonstrated. (Bilbao et al. 2013)

Based on the results of an interview that was conducted on March 16, 2019, at Senior High School (SHS) 2 Painan, out of five Biology teachers, only one teacher has started applying HOTS questions. The researcher conducted an interview with a teacher that the teacher had started to apply questions with the C4 cognitive level (analyzing) on certain questions but had not gotten used to it because the teacher only guided the questions in the textbook so that the teacher was not so proficient and did not know whether the questions made have met the criteria for HOTS questions or not. This can be seen from the analysis conducted by researchers on the matter of Daily Test for the Odd Semester Cell Division material for the 2019/2020 school year.

Table 1. Cognitive Level of Daily Test Questions on Cell Division Class X Odd Semester for 2019/2020 at Senior High School 2 Painan.

\begin{tabular}{lll}
\hline No & Cognitive Level & Percentage (\%) \\
\hline 1 & In view of (C1) & 5 \\
2 & Understand (C2) & 35 \\
3 & Applying (C3) & 35 \\
4 & Analyze (C4) & 25 \\
5 & Evaluating (C5) & 0 \\
6 & Creating (C6) & 0 \\
\hline
\end{tabular}

Based on the results of teacher interviews, it was also revealed that the teacher's ability to make thinking instruments of high-order thinking skills was still low because many teachers had difficulty making instruments with high-order thinking skills in schools. The obstacle that makes the teacher is the teacher who has difficulty in making questions that are identical to the questions using tables, graphs, schemes, schemes, narrative, and discourse, and the teacher also has to consider the heterogeneous abilities of students so that it is still difficult to answer questions with level high thinking skills. Therefore, it is necessary to develop higher-order thinking assessment instruments that can be used as a reference or guide by the teacher.

In addition, based on distributing questionnaires to 34 students of Class XI Mathematics and Science (MIPA) 1 Senior High School 2 Painan on March 16, 2019. The results of the distribution of the questionnaires indicated that the biology questions carried out mostly contained memorized questions, and students often memorize learning material before facing exams. So that students experience problems in answering high-level questions.

Researchers also tested 34 students of class XI MIPA 1, Senior High School 2 Painan on March 16, 2019. The questions tested were questions of high-order thinking skills that were valid by Ramadhani (2018) as many as 32 multiple choice questions on Protista material for class X semester 1. From the test questions, the average class score was 35,19. Based on the category of high-level thinking skills, the score of $21-40$ is in a low category (less), so that the average value obtained indicates that students' high-level thinking skills are still low. This happens because students are not used to and have not been trained to work on high-order thinking skills.

Therefore it is necessary to make efforts by educators in order to improve students' higher-order thinking skills. Fitzpatrick \& Schulz (2015) state that higher-order thinking skills can be developed using proper assessment. "The characteristics of the higherorder thinking skills assessment instrument are as follows,

a. Measure higher-order thinking skills

1) Ability to solve unfamiliar problems;

2) Ability to evaluate the strategies used to solve problems from various different points of view;

3) Finding new settlement models that are different from previous methods

b. Based on contextual and interesting problems (Contextual and Trending Topic)

c. Not routine and brings newness

Based on the statements that have been described, the problem of this research is how to produce a high-level thinking ability assessment instrument about cell division material for students of class XII, which is practical and the purpose of this study is to develop an instrument for assessing higher- 
order thinking skills of cell division material for practical class XII students.

\section{Method}

This type of research is research development (Development Research) by using a model of the 4-D (four-D models). This research was only conducted in three stages: define, design, develop, while the disseminate stage was not carried out due to time and cost limitations. This research was conducted at the Faculty of Mathematics and Natural Sciences, Padang State University, and Senior High School 2 Painan. The subjects of this study were validators and students. The validators consisted of two lecturers at the Department of Biology, Padang State University, and one biology subject teacher at Senior High School 2 Painan.

Practicality was carried out by two biology teachers and 34 students of class XII at Senior High School 2 Painan. The trial subjects consisted of 34 students of class XII Senior High School 2 Painan. The object of this research is an instrument for assessing higher-order thinking skills on Cell Division material for students of Class XII SMA/MA with a total of 50 items. The resulting product in the form of an instrument for assessing high-level thinking skills was tested at Senior High School 2 Painan on March 7, 2020. The research data was quantitative, and the data collection instrument was in the form of a practicality questionnaire.

\section{Result and Discussion}

The logical validity of the higher-order thinking skills assessment instrument

Logical validity of the higher-order thinking skills assessment instrument is carried out to prove whether the instrument has been developed valid or not by analyzing the appropriateness of the assessment instrument with the material, construction, language, and higher-order thinking skills. This logical validity was carried out by two biology lecturers of the State University of Padang and one teacher, using a validation sheet. Suggestions for improvement were obtained from the validator during the validation process to improve the higherorder thinking skills assessment instrument on cell division material. After correcting the questions in accordance with the suggestions of the validator, an analysis of the validity results is carried out. The validity analysis of the high-order thinking skills assessment instrument filled by the validator in the validation questionnaire is briefly shown in table 3 .
Table 3. Results of the Validity of the High-Level Thinking Ability Assessment Instrument

\begin{tabular}{llllllll}
\hline \multirow{2}{*}{ No Aspect } & \multicolumn{3}{c}{ Validator } & Amo- & $\begin{array}{l}\text { Validity } \\
\text { Value (\%) }\end{array}$ & Criteria \\
\cline { 2 - 6 } & 1 & 2 & 3 & unt & Value \\
\hline 1. & Theory & 35 & 31 & 31 & 97 & 89.81 & Valid \\
2. & Construction & 34 & 33 & 31 & 98 & 89.81 & Valid \\
3. & Language & 11 & 9 & 12 & 32 & 88.88 & Valid \\
4. & $\begin{array}{l}\text { High } \\
\text { level thinking }\end{array}$ & 19 & 17 & 16 & 52 & 88.88 & Valid \\
The total number of validity scores & & 356.09 & Valid \\
The average value of validity & & 89.02 & \\
\hline
\end{tabular}

Based on the results of the data analysis that has been done, it shows that the instrument for assessing higher-order thinking skills developed is in the valid category with an average validity value of $89.02 \%$.

In the material aspect, the results of data analysis were obtained with an average value of the three validators of $89.81 \%$, which was included in the valid category. This shows that the material in this higherorder thinking ability assessment instrument can be used to develop students' higher-order thinking skills in accordance with the Core Competencies and Basic Competencies in the 2013 Curriculum. This is in line with "Ministry of National Education (2017), the material developed must be appropriate with the demands of Core Competencies and Basic Competencies ".

The next aspect that is reviewed is the construction aspect, with the average value obtained, including the valid category with a value of $89.81 \%$. This shows that the subject matter has been clearly formulated, the subject matter and answer choices are just statements that are needed, the subject matter does not provide clues to the answer key, the question items do not depend on the answer to the previous question, and the answer choices in the form of numbers are arranged according to their size numbers and their chronology. "The questions are formulated briefly, clearly and firmly and are related to the material being asked" (Depdiknas, 2017).

In the language/culture aspect, the instrument for assessing high-order thinking skills obtained an average value of $88.88 \%$, which is considered valid. This shows that the instrument for assessing higher-order thinking skills that have been developed uses Indonesian that is good and correct, easy for students to understand, and the sentence formulation does not cause multiple interpretations. This is in accordance with the Ministry of National Education (2017), each question must use language that is in accordance with Indonesian language rules, and the choice of answers to questions does not repeat the same word or group of words. 
Judging from the aspect of higher-order thinking skills, this high-order thinking ability assessment instrument is valid with an average value of $88.88 \%$. This shows that the instrument for assessing higher-order thinking skills has measured students' cognitive level, including analyzing, evaluating, and creating. The percentage levels of the questions consisted of $\mathrm{C}_{4}=88 \%, \mathrm{C}_{5}=6 \%$, and $\mathrm{C}_{6}=$ $6 \%$. According to "Surapranata (2005), the validity of a concept is related to the extent to which the test has measured what should be measured".

Judging from all aspects, the average value of the logical validity test is $89.02 \%$ of the three validators. Based on these results, the instrument for assessing higher-order thinking skills for cell division material developed has met the criteria for logical validity and can be used in biology learning by the teacher as an assessment instrument. Before use, the assessment instrument must be tested on students to obtain empirical validity and the teacher to get the practical value of the assessment instrument.

\section{The practicality of higher-order thinking skills assessment instruments}

Practicality was carried out by two biology teachers of class XII of Senior High School 2 Painan by filling out a practicality questionnaire and 34 students of class XII of Senior High School 2 Painan by filling out a student response questionnaire). The practical results by biology teachers and students can be summarized in Tables 4 and 5 .

Table 4. Results of the Practicality of the Higher Level Thinking Ability Assessment Instrument by the Teacher

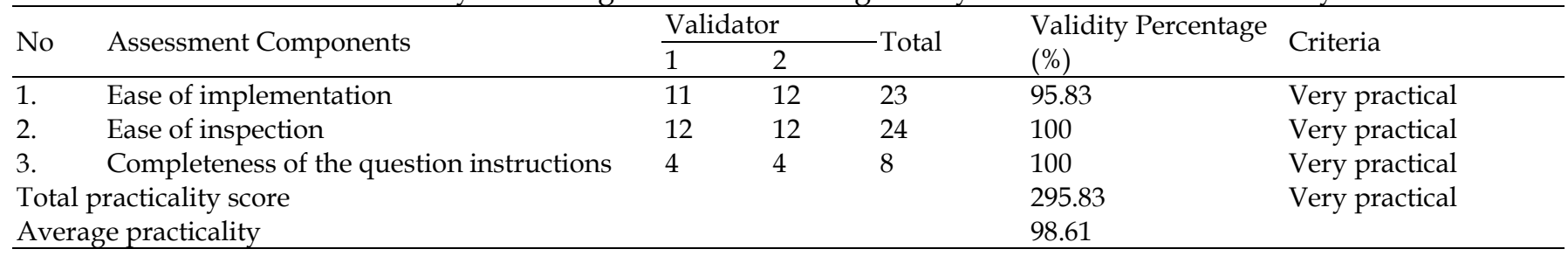

Table 5. Results of the Practicality of the Higher Level Thinking Ability Assessment Instrument by Students

\begin{tabular}{lllll}
\hline No & $\begin{array}{l}\text { No } \\
\text { Criteria }\end{array}$ & $\begin{array}{l}\text { Total } \\
\text { Value }\end{array}$ & $\begin{array}{l}\text { Correlation } \\
(\%)\end{array}$ & Criteria \\
\hline 1. & 1 & 114 & 83.82 & Practical \\
2. & 2 & 124 & 91.17 & Very Practical \\
3. & 3 & 117 & 86.02 & Practical \\
4. & 4 & 115 & 84.55 & Practical \\
5. & 5 & 124 & 91.17 & Very Practical \\
6. & 6 & 114 & 83.82 & Practical \\
7. & 7 & 114 & 83.82 & Practical \\
8. & 8 & 103 & 75.73 & Quite Practical \\
9. & 9 & 114 & 83.82 & Practical \\
10. & 10 & 116 & 85.29 & Practical \\
11. & 11 & 117 & 86.02 & Practical \\
12. & 12 & 117 & 86.02 & Practical \\
13. & 13 & 116 & 85.29 & Practical \\
14. & 14 & 113 & 83.08 & Practical \\
15. & 15 & 112 & 82.35 & Practical \\
Amount & & 1271 & Practical \\
Average & & 84.79 & \\
\hline
\end{tabular}

The implementation aspect obtained an average value of $95,83 \%$ with the very practical category. This shows that the time used in work is sufficient and effective, makes it easier for students to work on questions, and gives students the freedom to work on questions that are considered easier. This is in accordance with the opinion" Purwanto (2009) practicality is a quality that allows a general use to run by basing it on cost, the time required, ease of reporting and ease of interpretation of the results".

In terms of the inspection aspect, it is obtained an average value of $100 \%$ in the very practical category. This shows that this higher-order thinking ability assessment instrument makes it easier for teachers to check students' answers because the questions are equipped with answer sheets, answer keys, and guidelines/score scores.

Furthermore, seen from the aspect of the question instructions, it is obtained an average value of $100 \%$ in the very practical category. This is because the assessment instrument is equipped with clear instructions for questions. Instructions for questions on the instrument for assessing higher-order thinking skills that were developed consist of instructions on general questions and instructions for specific questions. This shows that the instructions on the questions on the higher-order thinking skills assessment instrument are easy for students to understand.

Based on the results of the practical analysis of the instrument for assessing high-order thinking skills for cell division material by the teacher, it was obtained an average value of $98.61 \%$, which is known that the assessment instrument has very practical criteria or categories. The instrument for assessing higher-order thinking skills is very practical to use as a guideline for assessing higher-order thinking skills in schools. 
Practicality is not only done to teachers, but also to students. Based on the results of the practical analysis of the instrument for assessing higher-order thinking skills for cell division material by these students, an average value of $84.79 \%$ was obtained. It is known that the assessment instrument has practical criteria or categories. The high-level assessment instrument that has been developed can help students test their ability to discuss questions with a high level of difficulty. Students are also helped with questions in the form of pictures, graphs, tables, and discourse in answering questions so that the average value of the practicality of teachers and students after adding up is $91,70 \%$ with the very practical category.

Tabel 6. Results of Empirical Validity Analysis of Higher-Level Thinking Ability Assessment Instruments

\begin{tabular}{|c|c|c|c|c|c|}
\hline \multirow[b]{2}{*}{ No } & \multirow[b]{2}{*}{ Criteria } & \multicolumn{3}{|l|}{ Empirical Validity } & \multirow[b]{2}{*}{ Amount } \\
\hline & & $\begin{array}{l}\text { Usual multiple choice } \\
\text { (Multiple Choice) }\end{array}$ & $\begin{array}{l}\text { Multiple choice of cause } \\
\text { and effect }\end{array}$ & $\begin{array}{l}\text { Multiple choice } \\
\text { of association }\end{array}$ & \\
\hline 1 & Valid & $\begin{array}{l}18 \text { questions } \\
(0.297-0.763)\end{array}$ & $\begin{array}{l}10 \text { questions } \\
(0.327-0.722)\end{array}$ & $\begin{array}{l}9 \text { questions } \\
(0.327-0.651)\end{array}$ & 37 questions \\
\hline 2 & Invalid & $\begin{array}{l}7 \text { questions } \\
(0.024-0.155)\end{array}$ & $\begin{array}{l}5 \text { questions } \\
(0.024-0.256)\end{array}$ & $\begin{array}{l}1 \text { questions } \\
(0.251)\end{array}$ & 13 questions \\
\hline
\end{tabular}

Empirical validity was obtained from item analysis using the ANATES version 4.09 program. The data obtained from the questions that had been tested on 34 students of class XII MIPA 1 Senior High School 2 Painan were 50 items. The assessment instrument is said to be valid if it has empirical validity in accordance with experience, namely experiences that have been measured based on the trials carried out. This is in accordance with Arikunto's (2012) opinion, which states that an instrument can be said to have empirical validity if after being tested from its experience ". Based on these results, the instrument for assessing higherorder thinking skills for cell division material developed has met the criteria for empirical validity. From the results of this analysis, it was found that 37 questions were said to be valid with a percentage of $74 \%$, and 13 questions were invalid with a percentage of $26 \%$ based on their empirical validity. Based on the test results, the valid questions were obtained from 50 questions, namely 37 questions. $\mathrm{C} 4=92 \%, \mathrm{C} 5=3 \%$, and $\mathrm{C} 6=5 \%$ consisting of $\mathrm{C} 4=34$ questions, $\mathrm{C} 5=1$ question, and $\mathrm{C} 6=2$ questions after going through the process of testing questions to students.

\section{The reliability of the instrument for assessing higher-} order thinking skills

Reliability is the state of the instrument that shows reliable or consistent measurement results). Results of analysis about the use ANATES 4.09 version, instrument ratings, and higher level thinking skills developed have been reliable with a value of 0,89 . This assessment instrument is said to be reliable if it gives the same results. This is in accordance with the opinion of Ugulu et al. (2013), the reliable instrument is an instrument that is carried out at different times and the measurements made by different people, the results remain the same.

The development of HOTS instruments is an important thing in science learning because students need HOTS skills in the 21st century (Abidinsyah et al., 2019; Anagun, 2018; Dewi et al., 2020; Camacho \& Legare, 2015; Farisi, 2016; Marlina \& Rahmi, 2021; Santi et al., 2019). Students are required to be able to contribute to solving science problems in their neighborhood. HOTS ability, which consists of analyzing, evaluating, and creating, is an important thing to support problem solving efforts that students must do so that the HOTS-based instrument development innovation needs to be done. In addition, it is also necessary to develop teaching materials and other components to support HOTS-based learning. Efforts to use technology-based learning media can also be applied to increase HOTS (Boholano, 2017; Gündüz et al., 2016; Hwang et al., 2018).

\section{Conclusions}

Based on the research that has been done, it can be concluded that through the development process of $4 \mathrm{D}$ models an instrument for assessing high-level thinking skills about cell division material has been produced for students of class XII SMA/MA who get an average logical validity score of $89.02 \%$ with the valid category, the average practicality value was $91.70 \%$ with the very practical category, the results of the empirical validity data analysis obtained 37 questions out of 50 questions with a value of $74 \%$, the reliability was 0.89 with a very high category, with a moderate level of difficulty with a percentage of 32, 3$58.8 \%$, excellent differentiation $14 \%$, $46 \%$ good, $24 \%$ good enough, and $91.5 \%$ option quality with very good category $61 \%$ and $30.5 \%$ good. Based on the research 
done, the researchers suggest that researchers who will make HOTS questions add insight and be more creative in making interesting discourses so that making questions becomes easier. The test instrument ratings ability to think this high should be done in coordination with the subject teachers up first so that when the implementation of the working time about unused by the up activity of learning, and needed review the material that will be tested before the trial is the assessment tool advanced thinking abilities to get maximum results.

\section{References}

Abidinsyah, A., Ramdiah, S., \& Royani, M. (2019). The implementation of local wisdom-based learning and HOTS-based assessment: Teacher survey in Banjarmasin. JPBI (Jurnal Pendidikan Biologi Indonesia), 5(3), 407-414. doi: https://doi.org/10.22219/jpbi.v5i3.9910

Anagun, S. S. (2018). Teachers' perceptions about the relationship between 21st century skills and managing constructivist learning environments. International Journal of Instruction, 11(4), 825-840. doi: https://doi.org/10.12973/iji.2018.11452a

Anderson, L. W., Krathwohl, D. R., Airiasian, W., Cruikshank, K. A., Mayer, R. E., Pintrich, P. R., Raths, J., \& Wittrock, M. C. (2001). A taxonomy for learning, teaching and assessing: A revision of bloom's taxonomy of educational objectives. Longman.

Arikunto, S. (2012). Dasar-Dasar Evaluasi Pendidikan. Bumi Aksara. [Indonesian]

Boholano, H. B. (2017). Smart social networking: 21st century teaching and learning skills. Research in Pedagogy, 7(1), 21-29. doi: https://doi.org/10.17810/2015.45

Bilbao, P.P., Dayagbil, F.T., \& Corpuz, B.B. (2013). Curriculum Development. Lorimar Publishing, Inc. Manila, Philippines.

Camacho, D. J., \& Legare, J. M. (2015). Opportunities to create active learning techniques in the classroom. Journal of Instructional Research, 4, 38$45 . \quad$ Retrieved from: https://eric.ed.gov/?id=EJ1127696

Dewi, N., Rahmi, Y., Alberida, H., \& Darussyamsu, R. (2020). Validitas dan Reliabilitas Instrumen Penilaian Kemampuan Berpikir Tingkat Tinggi ten-tang Materi Hereditas untuk Peserta Didik SMA/MA. Jurnal Eksakta Pendidikan (JEP), 4(2), 138-146. doi: https://doi.org/10.24036/jep/vol4iss2/512 [Indonesian]

Farisi, M. I. (2016). Developing the 21 st-century social studies skills through technology integration. Turkish Online Journal of Distance Education-
TOJDE,
17(1),
16-30.
doi:

https://doi.org/10.17718/tojde.47374

Fitzpatrick, B., \& Schulz, H. (2015). Do Curriculum Outcomes and Assessment Activities in Science Encourage Higher Order Thinking? Canadian Journal of Science, Mathematics and Technology Education, 15(2), 136-154. https://doi.org/10.1080/14926156.2015.1014074

Gündüz, A. Y., Alemdağ, E., Yaşar, S., \& Erdem, M. (2016). Design of a problem-based online learning environment and evaluation of its effectiveness. The Turkish Online Journal of Educational Technology, 15(3), 49-57. https://doi.org/10.1017/CBO9781107415324.004

Hwang, G.-J., Lai, C.-L., Liang, J.-C., Chu, H.-C., \& Tsai, C.-C. (2018). A long-term experiment to investigate the relationships between high school students' perceptions of mobile learning and peer interaction and higher-order thinking tendencies. Educational Technology Research and Development, 66(1), 75-93. https://doi.org/10.1007/s11423$\underline{017-9540-3}$

Lince, R. (2016). Creative Thinking Ability to Increase Student Mathematical of Junior High School by Applying Models Numbered Heads Together. Journal of Education and Practice, 7(6), 206-212. Retrieved from: https://eric.ed.gov/?id=EJ1092494

Mahoney, J. W., \& Harris-Reeves, B. (2019). The effects of collaborative testing on higher order thinking: Do the bright get brighter? Active Learning in Higher Education, 20(1), 25-37. https://doi.org/10.1177/1469787417723243

Marlina, D. I., \& Rahmi, Y. L. (2021). Assessment of Higher Order Thinking Skills in Genetic Learning: A Validity, Practicality, and Reliability. Journal of Physics: Conference Series, 1940(1), 12121. https://doi.org/10.1088/17426596/1940/1/012121.

Santi, D. H., Prayitno, B. A., \& Muzzazinah, M. (2019). Problem solving process and creative thinking of students in ecosystem issue. JPBI (Jurnal Pendidikan Biologi Indonesia), 5(3), 537-548. https://doi.org/10.22219/jpbi.v5i3.9647

Sesen, B. A., \& Tarhan, L. (2010). Promoting active learning in high school chemistry: Learning achievement and attitude. Procedia - Social and Behavioral Sciences, 2(2), 2625-2630. https://doi.org/10.1016/j.sbspro.2010.03.384

Surapranata, S. (2005). Panduan Penulisan Tes Tertulis ImplementasiKurikukum 2004. Bandung: Remaja Rosdakarya. [Indonesian]

Tajudin, N. M., \& Chinnappan, M. (2016). The link between higher order thinking skills, representation and concepts in enhancing TIMSS 
tasks. International Journal of Instruction, 9(2), 199-

214. doi: https://doi.org/10.12973/iji.2016.9214a

Ugulu, I., Sahin, M., \& Baslar, S. (2013). High school students' environmental attitude: Scale development and validation. International Journal of Educational Sciences, 5(4), 415-424. https://doi.org/10.1080/09751122.2013.11890103 